\title{
Response of Organic Matter Decomposition to No-Tillage Adoption Evaluated by the Tea Bag Technique
}

\author{
David Houben * (D), Michel-Pierre Faucon and Anne-Maïmiti Mercadal \\ AGHYLE, UniLaSalle, CEDEX, 60026 Beauvais, France; michel-pierre.faucon@unilasalle.fr (M.-P.F.); \\ anne-maimiti.mercadal@unilasalle.fr (A.-M.M.) \\ * Correspondence: david.houben@unilasalle.fr or david.houben@outlook.com; Tel.: +33-3-44-06-93-45
}

Received: 2 July 2018; Accepted: 24 July 2018; Published: 25 July 2018

\begin{abstract}
Organic matter $(\mathrm{OM})$ decomposition is a fundamental ecosystem service in conservation agriculture, but the response of this process to the conversion from conventional tillage (CT) to no-tillage (NT) systems is not fully understood, especially during the transition period. Here, using a litterbag experiment (tea bag technique), we studied OM decomposition in a chronosequence of NT fields of different ages since conversion from CT (1 to 7 years) around Beauvais (northern France). We found that, in contrast with physico-chemical soil properties, the decomposition of both high quality (green tea) and low quality (rooibos tea) organic matter was significantly correlated with the NT age. Irrespective of the OM quality, the OM mass losses linearly increased with the time span since conversion from CT to NT. Taken together, our results suggest that adopting NT practices provides more favorable habitats for microorganisms involved in OM decomposition.
\end{abstract}

Keywords: decomposition; tillage; litterbag; tea bag; soil functioning; soil quality; indicator

\section{Introduction}

The adoption of conservation tillage practices has been increasingly advocated to reduce the depressive effects of intensive farming on soil quality; alleviate greenhouse gas emissions through reducing fossil fuel consumption; and improve net returns by reducing operating, labor, and input costs [1]. A fundamental principle of conservation tillage is no-tillage (NT; also known as drilling and zero tillage), which consists of sowing crops without any prior loosening of the soil by cultivation and keeping $30-100 \%$ of the surface covered with plant residues [2]. In Europe, the adoption of NT is much less widespread than in other countries [3] and, although many studies have shown that NT implementation might provide other advantages (e.g., soil C sequestration, soil biodiversity enhancement, greater crop yield, weed suppression, etc.), recent studies indicate that these benefits may not be as widely observed as previously thought $[2,4,5]$. In particular, whereas many studies have reviewed the long-term effect of NT [6,7], the system behavior during the transition period is still poorly documented [8].

An essential building block of developing sustainable farming practices is to evaluate their effect on soil quality [9]. Soil quality is defined as the capacity of a specific kind of soil to effectively function through supporting plant and animal survival without threatening environmental quality [10]. Indicators of soil quality should be sensitive to management and changes in soil functioning, easily measurable and accessible to agricultural specialists, producers, conservationists, and policy makers [11]. As a result of the availability of easy analysis techniques, soil quality studies initially focused on chemical and physical soil properties. However, these properties are occasionally not sensitive to changes that occur in soil, especially in the short run [12]. To overcome this, biological 
soil properties have been increasingly used as they were found to respond to small changes in soil conditions, thus acting as early and sensitive indicators of subtle alteration of soil functioning and, ultimately, soil quality $[13,14]$. For example, soil enzyme activities have been proposed as suitable indicators because of their rapid response to change in soil management and their close link to soil organic matter (OM) dynamics [15], which plays a key role in driving soil processes and properties [16]. However, most of the analyses related to soil biological attributes are too costly to be applied by end-users such as farmers.

Recently, Keuskamp et al. [17] introduced a new and innovative methodology for studying the decomposition of organic materials in situ and, more generally, the soil functioning. Commercially available tea bags are used as litterbags and the approach has the benefits of being a cost-effective and well-standardized method that can be used all over the world. By gathering data from 336 sites across different ecosystems, Djukic et al. [18] have evidenced that this technique might be successfully used to identify the drivers of early stage litter decomposition at both global and biome scales. Tóth et al. [19] have also shown that this approach might be used as an ecological indicator to assess impacts of agri-environmental schemes on soil functioning. Such observations gave rise to the idea of using the tea bag technique to detect change in the potential of OM decomposition and, more generally, change in the soil functioning, following the conversion from conventional tillage (CT) to NT practices.

The objective of the present work was therefore two-fold: (i) to gain insight into the impact of NT on OM decomposition during the transition period using the tea bag technique, and (ii) to test the short-term sensitivity of this approach to the adoption of NT, thereby allowing us to determine whether or not it might be used earlier in the process of transition to NT to gauge short-term impacts of NT on soil functioning. For this purpose, we investigated tea decomposition in soils along a chronosequence of 13 plots of different years under NT in northern France. This approach allowed us to isolate the effect of the time factor from other factors controlling OM decomposition, namely climatic conditions and soil properties [18].

\section{Materials and Methods}

\subsection{Study Area and Soil Sampling}

One conventional and 12 NT farms with the same preceding cash crop (i.e., winter wheat) were investigated around Beauvais (northern France, $49^{\circ} 43^{\prime} \mathrm{N} ; 2^{\circ} 08^{\prime} \mathrm{W}$; Figure 1). The climate was oceanic, with mean rainfall of $669 \mathrm{~mm}$ per year and mean temperature of $10.7^{\circ} \mathrm{C}$. The selection of NT farms was based on a synchronic approach (space-for-time substitution) in order to obtain a chronosequence of farmer's field managed under NT for different lengths of time. The time since adoption of NT ranged from 1 to 7 years. All soils were loess-derived Hortic Luvisol [20].

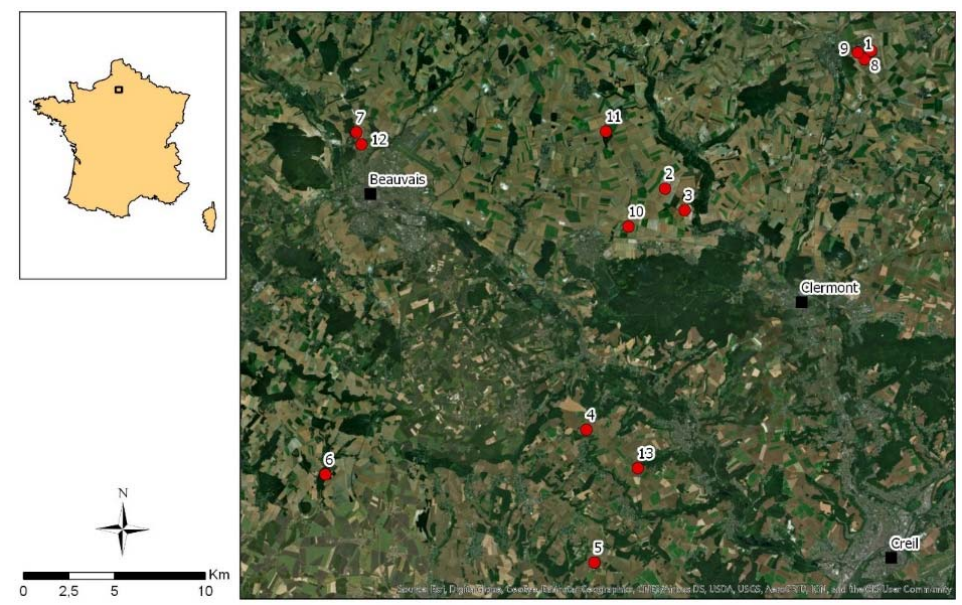

Figure 1. Locations of the sampling sites. 


\subsection{Soil Sampling and Analyses}

In each site, four sub-sampling sites were randomly selected, avoiding atypical areas. At each sub-sample site, approximately $1.0 \mathrm{~kg}$ of surface soil horizon $(0-10 \mathrm{~cm})$ was collected by composite sampling. The collected soil was then air-dried at ambient temperature; sieved $(2 \mathrm{~mm})$; and characterized for $\mathrm{pH}$ in water (1:5 soil/solution ratio), total $\mathrm{C}$ and $\mathrm{N}$ content using the Dumas combustion method, and texture using the pipette method. Cation exchange capacity (CEC) was measured using $\mathrm{CH}_{3} \mathrm{COONH}_{4} 1 \mathrm{~mol} \mathrm{~L}^{-1}$ buffered at $\mathrm{pH}=7$ [21]. The available nutrient $(\mathrm{Ca}, \mathrm{K}$, $\mathrm{Mg}, \mathrm{P}$ ) concentrations were determined using the ammonium acetate-EDTA soil test [22]. Selected soil properties are shown in Table 1.

Table 1. Selected soil properties. NT—no-tillage; CEC—cation exchange capacity.

\begin{tabular}{|c|c|c|c|c|c|c|c|c|c|}
\hline Site & $\begin{array}{l}\text { NT Age } \\
\text { (Years) }\end{array}$ & $\begin{array}{l}\text { Clay } \\
(\%)\end{array}$ & $\begin{array}{l}\text { Silt } \\
(\%)\end{array}$ & $\begin{array}{c}\text { Sand } \\
(\%)\end{array}$ & $\mathrm{pH}$ & $\begin{array}{c}\text { CEC } \\
\left(\mathrm{cmol}_{\mathrm{c}} \mathrm{kg}^{-1}\right)\end{array}$ & $\underset{(\%)}{\text { Organic } C}$ & $\begin{array}{c}\text { Total N } \\
(\%)\end{array}$ & $\mathrm{C} / \mathrm{N}$ \\
\hline 1 & 0 & 17.00 & 72.93 & 10.07 & 7.13 & 10.74 & 11.79 & 0.12 & 9.90 \\
\hline 2 & 1 & 24.14 & 65.63 & 10.23 & 8.37 & 17.10 & 10.77 & 0.12 & 9.26 \\
\hline 3 & 1 & 16.42 & 72.03 & 11.55 & 6.69 & 9.42 & 17.94 & 0.18 & 9.93 \\
\hline 4 & 1 & 23.58 & 52.15 & 24.27 & 8.06 & 15.06 & 16.20 & 0.19 & 8.69 \\
\hline 5 & 1 & 29.10 & 57.31 & 13.60 & 8.13 & 15.68 & 13.49 & 0.14 & 9.49 \\
\hline 6 & 1 & 15.84 & 72.81 & 11.35 & 7.98 & 8.56 & 13.03 & 0.12 & 11.23 \\
\hline 7 & 2 & 18.42 & 72.13 & 9.45 & 7.11 & 11.06 & 10.14 & 0.11 & 9.40 \\
\hline 8 & 4 & 22.41 & 67.24 & 10.35 & 8.07 & 15.60 & 15.91 & 0.14 & 11.09 \\
\hline 9 & 4 & 15.63 & 74.31 & 10.06 & 7.21 & 10.60 & 12.53 & 0.12 & 10.14 \\
\hline 10 & 6 & 25.05 & 64.53 & 10.42 & 8.49 & 16.94 & 12.41 & 0.16 & 8.03 \\
\hline 11 & 6 & 13.95 & 64.09 & 21.96 & 8.40 & 10.28 & 13.82 & 0.15 & 9.22 \\
\hline 12 & 6 & 28.33 & 55.84 & 15.83 & 7.88 & 21.18 & 21.24 & 0.21 & 10.27 \\
\hline 13 & 7 & 18.78 & 73.57 & 7.65 & 7.57 & 12.86 & 14.09 & 0.14 & 10.24 \\
\hline
\end{tabular}

\subsection{Tea Bag Experiment}

The tea bag technique, recently developed by Keuskamp et al. (2013), was used in this study as a potential indicator of change in soil functioning following NT adoption. On 1 May 2015, at each site, two plastic tea bags containing either Lipton green tea or Lipton rooibos tea were buried pairwise in the soil at a depth of $5 \mathrm{~cm}$ and left in the soil over a 30-day period in four replicates. The mesh size of the tea bags is $0.25 \mathrm{~mm}$. The initial element composition of both teas was analyzed by inductively coupled plasma-atomic emission spectroscopy (ICP-AES; Jarrell Ash) after grinding and digesting the dried biomass in a tri-acid mixture $\left(\mathrm{HClO}_{4}, \mathrm{HNO}_{3}\right.$, and $\left.\mathrm{HF}\right)$ [23]. Green tea presents a high hydrolysable fraction (i.e., $0.842 \mathrm{~g} \mathrm{~g}^{-1}$ ), low $\mathrm{C} / \mathrm{N}$ and $\mathrm{C} / \mathrm{P}$ ratios (i.e., 12.23 and 329, respectively), and high nutrient concentration (Table 2), and can therefore be considered as high quality OM. By contrast, with a lower hydrolysable fraction (i.e., $0.552 \mathrm{~g} \mathrm{~g}^{-1}$ ), higher $\mathrm{C} / \mathrm{N}$ and $\mathrm{C} / \mathrm{P}$ ratios (i.e., 42.87 and 1219 , respectively), and lower nutrient concentration (Table 2), rooibos tea is considered a low quality $\mathrm{OM}[24,25]$. At the end of the incubation period, tea bags were collected, cleaned, and dried at $70{ }^{\circ} \mathrm{C}$ until the weight remained constant and litter mass loss was then calculated, following the guidelines by Keuskamp et al. (2013). 
Table 2. Composition of green tea and rooibos tea. Values are mean $\pm \mathrm{SE}$.

\begin{tabular}{ccc}
\hline Properties & Green Tea & Rooibos Tea \\
\hline Hydrolysable fraction ${ }^{1}\left(\mathrm{~g} \mathrm{~g}^{-1}\right)$ & 0.842 & 0.552 \\
$\mathrm{C}^{1}(\%)$ & 49.055 & 50.511 \\
$\mathrm{~N}^{1}(\%)$ & 4.019 & 1.185 \\
$\mathrm{Al}\left(\mathrm{mg} \mathrm{kg}^{-1}\right)$ & $1461 \pm 21$ & $86 \pm 1$ \\
$\mathrm{Ca}\left(\mathrm{mg} \mathrm{kg}^{-1}\right)$ & $5850 \pm 64$ & $1918 \pm 132$ \\
$\mathrm{Fe}\left(\mathrm{mg} \mathrm{kg}^{-1}\right)$ & $107 \pm 4$ & $98 \pm 3$ \\
$\mathrm{~K}\left(\mathrm{mg} \mathrm{kg}^{-1}\right)$ & $15251 \pm 88$ & $2799 \pm 113$ \\
$\mathrm{Mg}\left(\mathrm{mg} \mathrm{kg}^{-1}\right)$ & $2108 \pm 4$ & $1561 \pm 48$ \\
$\mathrm{Mn}\left(\mathrm{mg} \mathrm{kg}^{-1}\right)$ & $1030 \pm 5$ & $53 \pm 2$ \\
$\mathrm{Na} \mathrm{(mg} \mathrm{kg}$ & -1 \\
$\mathrm{P}\left(\mathrm{mg} \mathrm{kg}^{-1}\right)$ & $599 \pm 51$ & $2832 \pm 10$ \\
$\mathrm{~S}\left(\mathrm{mg} \mathrm{kg}^{-1}\right)$ & $2781 \pm 15$ & $425 \pm 17$ \\
& $1489 \pm 20$ & $415 \pm 14$ \\
\hline
\end{tabular}

\subsection{Statistical Analyses}

After testing the homogeneity of variances and normality of soil data using Levene and Shapiro-Wilk tests, respectively, a paired $t$-test was used to compare litter decomposition between green tea and rooibos tea. Pearson's correlation coefficients $(r)$ were used to investigate the relationships between data. Analysis of variance (ANOVA) was used to evaluate the effects of NT age on tea decomposition. All statistical analyses were performed using $\mathrm{R}$ version 3.2.2.

\section{Results and Discussion}

Soil properties were not significantly correlated with the time span since the adoption of NT (NT age; Table 3), which is in line with previous studies indicating that physico-chemical properties change very slowly after modifying management practices [15]. More generally, our results suggest that physico-chemical properties alone were not sensitive enough to track any early change in soil quality following the conversion from CT to NT.

Table 3. Pearson's correlation coefficients between organic carbon (OC) and total $\mathrm{N}$ concentrations; $\mathrm{C} / \mathrm{N}$ ratio; $\mathrm{pH}$; cation exchange capacity (CEC); available $\mathrm{Ca}, \mathrm{K}, \mathrm{Mg}$, and $\mathrm{P}$ concentrations; green tea (GT) and rooibos (RT) mass losses; and no-tillage age (NT age).

\begin{tabular}{|c|c|c|c|c|c|c|c|c|c|c|c|}
\hline & $\mathbf{N}$ & C:N & $\mathrm{pH}$ & CEC & $\mathrm{Ca}$ & $\mathbf{K}$ & Mg & $\mathbf{P}$ & GT Mass Loss & RT Mass Loss & NT Age \\
\hline OC & $0.90^{* * *}$ & 0.25 & -0.05 & 0.39 & 0.27 & $0.75^{* *}$ & 0.28 & 0.11 & 0.34 & 0.22 & 0.27 \\
\hline $\mathrm{N}$ & & -0.19 & 0.10 & 0.49 & 0.44 & 0.66 * & 0.44 & 0.11 & 0.33 & 0.33 & 0.29 \\
\hline $\mathrm{C} / \mathrm{N}$ & & & -0.30 & -0.26 & -0.31 & 0.14 & -0.33 & -0.06 & 0.02 & -0.22 & -0.05 \\
\hline $\mathrm{pH}$ & & & & 0.53 & 0.37 & -0.26 & 0.28 & 0.47 & 0.20 & 0.57 * & 0.30 \\
\hline CEC & & & & & 0.39 & 0.48 & 0.43 & 0.26 & 0.34 & 0.41 & 0.31 \\
\hline $\mathrm{Ca}$ & & & & & & -0.02 & $0.98^{* * *}$ & -0.37 & -0.04 & 0.17 & -0.22 \\
\hline K & & & & & & & 0.09 & 0.17 & 0.38 & 0.03 & 0.28 \\
\hline $\mathrm{Mg}$ & & & & & & & & -0.40 & -0.06 & 0.13 & -0.23 \\
\hline $\mathrm{P}$ & & & & & & & & & 0.30 & 0.33 & 0.50 \\
\hline GT mass loss & & & & & & & & & & $0.65 *$ & $0.80^{* * *}$ \\
\hline RT mass loss & & & & & & & & & & & $0.81^{* * *}$ \\
\hline
\end{tabular}

$$
{ }^{*} p<0.05 ;{ }^{* *} p<0.01 ;{ }^{* * *} p<0.001
$$

The effect of OM quality is known to be one of the key drivers of litter decomposition [26]. As expected, we found that high quality OM (green tea) was significantly (paired $t$-test, $p<0.001$, $n=13$ ) more decomposed than low quality OM (rooibos tea; Figure 2), confirming the direct influence of OM quality on mass loss rates [18,27]. 


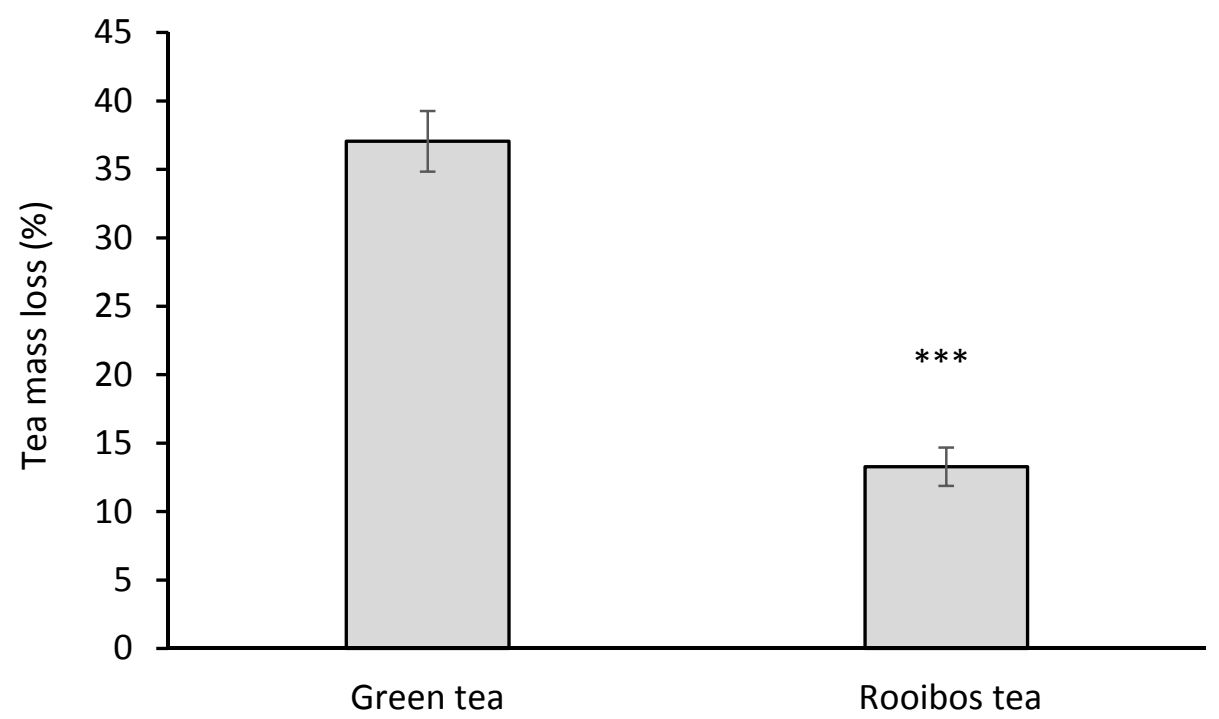

Figure 2. Average decomposed mass of green tea (high quality organic matter (OM)) and rooibos tea (low quality OM). Data are presented as mean \pm standard deviation. Asterisks denote significant differences (paired $t$-test, ${ }^{* * *} p<0.001, n=13$ ).

More importantly, the time span since conversion from CT to NT was significantly correlated with and had a significant impact on the mass lost by both teas (Tables 3 and 4, respectively). This indicates that, by contrast to physico-chemical properties, the tea bag technique is sensitive to changes in tillage practices and, as a cost-effective and easily accessible method, it might possibly be used by end-users as a proxy to track change in soil functioning in response to NT adoption. Moreover, the positive linear relationship between OM decomposition and the age of NT (Figure 3) is especially meaningful as it might, at least in part, explain why studies reported that OM mineralization was unaffected in the short-term (e.g., Kristensen et al., 2013), but increased in the long-term (e.g., Schoenau and Campbell, 1996) after converting CT to NT. Consistent with Zuber and Villamil (2016) highlighting higher microbial activity in long-term NT than in short-term NT, our results also indicate that the microbial decomposition activity increases with the time span since the adoption of NT. High quality OM usually favors the development of opportunistic bacterial taxa that increase with the greatest quantity of labile C compounds. Conversely, lower OM quality promotes oligotrophic microbial communities, dominated by fungi, that are more able to degrade recalcitrant compounds, such as lignin or litters with high $\mathrm{C} / \mathrm{N}$ ratios [28,29]. As the decomposition of both high and low quality OM (green tea and rooibos tea, respectively) was positively related to NT age, our results provide indirect evidence that the activity of both opportunistic bacteria and fungi increased with the time span since the conversion from CT to NT. Although our findings should be substantiated by further microbiological analyses, including microbial biomass and microbial community profiling, they are consistent with previous investigations and likely result from the lack of disruption of the hyphal network under NT [30,31] and the regular supply of $C$ by cover crop, as well as the increase of soil aggregation over time under NT [32], which provides a variety of new habitats and micro-environments for soil microbial communities involved in the short-term processing of readily-decomposable organic $C[12,33,34]$.

Many studies have shown that NT might increase microbial abundance, often resulting in higher microbial activity [35-37]. However, this does not necessarily lead to higher organic matter decomposition. In the short-term, tillage is known to cause a sharp increase of $\mathrm{CO}_{2}$ flux in the first days after soil-disturbance. In the long-run, studies show contradictory results as the decomposition of organic matter was found to be higher [38,39], similar [4,40], or lower [41-43] under CT compared with NT. These inconsistencies across studies have been hypothetically attributed to differences of water content; climate; and the amount, type, and stratification of organic matter [2]. Here, our study 
indicates that the NT age might also be behind some of these contradictory conclusions reported in studies.

Table 4. Results from analysis of variance (ANOVA) examining the effects of no-tillage age on green tea and rooibos tea decomposition. DF-degrees of freedom.

\begin{tabular}{ccccc}
\hline & DF & Sum Sq & $\boldsymbol{F}$ Value & $\boldsymbol{p}$ Value \\
\hline Green tea & 5 & 0.595 & 10.68 & $<0.001$ \\
Rooibos tea & 5 & 0.332 & 7.30 & $<0.001$ \\
\hline
\end{tabular}

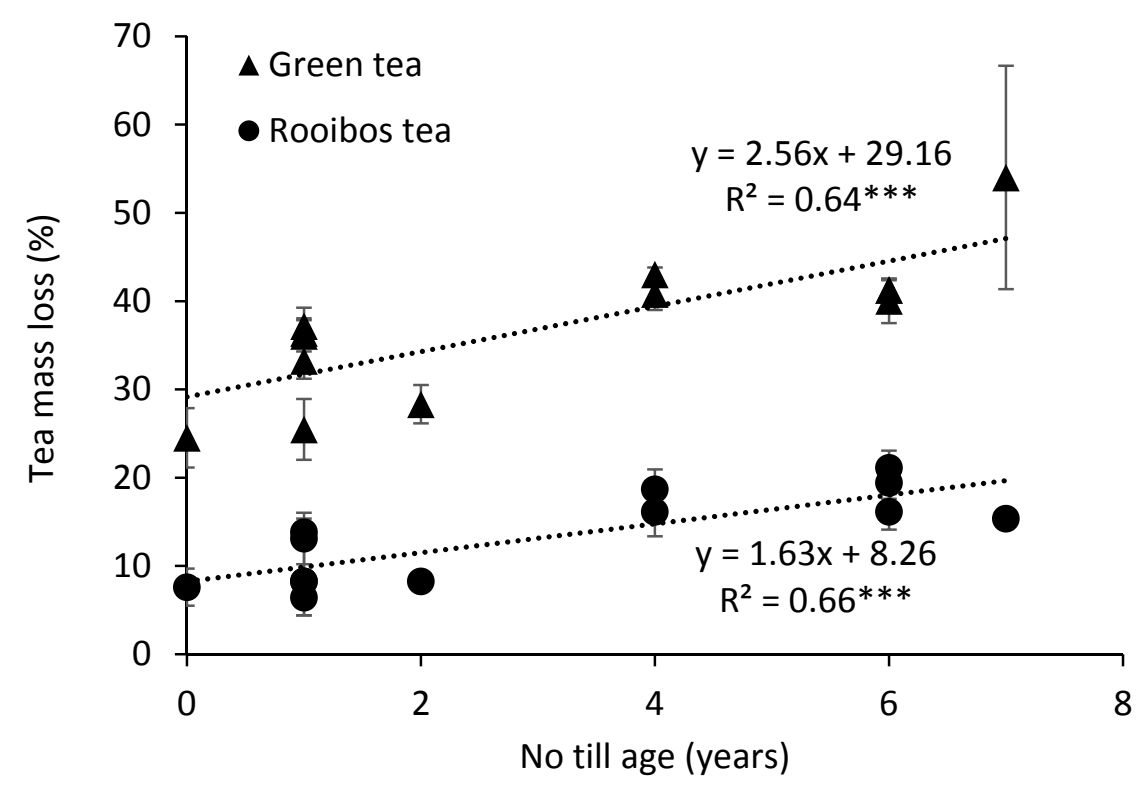

Figure 3. Relationship between green tea and rooibos tea mass loss and years since conversion from CT to NT $\left.{ }^{* * *} p<0.001\right)$. Data are presented as mean \pm standard deviation.

\section{Conclusions}

Organic matter decomposition is a fundamental ecosystem service in conservation agriculture because it regulates soil fertility, nutrient recycling, $\mathrm{C}$ sequestration, and ultimately plant growth and productivity $[44,45]$. The chronosequence approach used in the present study allowed us to isolate time from the other factors controlling this process, namely climatic conditions and soil properties [18]. Our study indicates that converting CT to NT might favor the decomposition of both low and high quality OM during the transition period. It must be noted that, even though the 30-day period of this experiment provides insight into the early stage of organic matter decomposition, long term decomposition involves other litter components [18], thus our results should not be extrapolated over the long run. Moreover, although our findings are in line with the accumulating evidence supporting the idea that microbial activity is higher in NT soil relative to CT soil, this work was a one-time area-specific study. It will be thus essential to perform further research under other periods of the year, as well as in various soil and climate contexts to assess the generality of the tea bag technique to be used as an indicator of change in soil functioning following NT adoption.

Despite these limitations, our data support the fact that increased biological activity is a likely outcome of adopting NT management. More generally, this preliminary study suggests that the tea bag approach may help us better understand the consequence of adopting NT on soil organic matter dynamics.

Author Contributions: D.H., M.-P.F. and A.-M.M. conceived and designed the experiments; D.H. analyzed the data; D.H. wrote the paper with inputs from M.-P.F and A.-M.M. 
Funding: This research received no external funding.

Acknowledgments: We thank the "ASET 156" students and Anne Iserentant for technical assistance. We are grateful to all the farmers who provided the information about their management of the soil and sampling permission. Romain Armand is gratefully acknowledged for his assistance for the map. This work was funded by the Association pour la Promotion d'une Agriculture Durable (APAD).

Conflicts of Interest: The authors declare no conflict of interest. The founding sponsors had no role in the design of the study; in the collection, analyses, or interpretation of data; in the writing of the manuscript; and in the decision to publish the results.

\section{References}

1. Kertész, Á.; Madarász, B. Conservation Agriculture in Europe. Int. Soil Water Conserv. Res. 2014, 2, 91-96. [CrossRef]

2. Soane, B.D.; Ball, B.C.; Arvidsson, J.; Basch, G.; Moreno, F.; Roger-Estrade, J. No-till in northern, western and south-western Europe: A review of problems and opportunities for crop production and the environment. Soil Tillage Res. 2012, 118, 66-87. [CrossRef]

3. Lahmar, R. Adoption of conservation agriculture in Europe: Lessons of the KASSA project. Land Use Policy 2010, 27, 4-10. [CrossRef]

4. Autret, B.; Mary, B.; Chenu, C.; Balabane, M.; Girardin, C.; Bertrand, M.; Grandeau, G.; Beaudoin, N. Alternative arable cropping systems: A key to increase soil organic carbon storage? Results from a 16 year field experiment. Agric. Ecosyst. Environ. 2016, 232, 150-164. [CrossRef]

5. Dimassi, B.; Cohan, J.-P.; Labreuche, J.; Mary, B. Changes in soil carbon and nitrogen following tillage conversion in a long-term experiment in Northern France. Agric. Ecosyst. Environ. 2013, 169, 12-20. [CrossRef]

6. Bai, Z.; Caspari, T.; Gonzalez, M.R.; Batjes, N.H.; Mäder, P.; Bünemann, E.K.; de Goede, R.; Brussaard, L.; Xu, M.; Ferreira, C.S.S.; et al. Effects of agricultural management practices on soil quality: A review of long-term experiments for Europe and China. Agric. Ecosyst. Environ. 2018, 265, 1-7. [CrossRef]

7. van Capelle, C.; Schrader, S.; Brunotte, J. Tillage-induced changes in the functional diversity of soil biota-A review with a focus on German data. Eur. J. Soil Biol. 2012, 50, 165-181. [CrossRef]

8. Ferrara, R.M.; Mazza, G.; Muschitiello, C.; Castellini, M.; Stellaccia, A.M.; Navarro, A.; Lagomarsino, A.; Vitti, C.; Rossi, R.; Rana, G. Short-term effects of conversion to no-tillage on respiration and chemical-physical properties of the soil: A case study in a wheat cropping system in semi-dry environment. Ital. J. Agrometerol. 2017, 22, 47-58.

9. Zuber, S.M.; Behnke, G.D.; Nafziger, E.D.; Villamil, M.B. Multivariate assessment of soil quality indicators for crop rotation and tillage in Illinois. Soil Tillage Res. 2017, 174, 147-155. [CrossRef]

10. de Paul Obade, V.; Lal, R. Towards a standard technique for soil quality assessment. Geoderma 2016, 265, 96-102. [CrossRef]

11. Doran, J.W.; Zeiss, M.R. Soil health and sustainability: Managing the biotic component of soil quality. Appl. Soil Ecol. 2000, 15, 3-11. [CrossRef]

12. Panettieri, M.; Knicker, H.; Murillo, J.M.; Madejón, E.; Hatcher, P.G. Soil organic matter degradation in an agricultural chronosequence under different tillage regimes evaluated by organic matter pools, enzymatic activities and CPMAS ${ }^{13}$ C NMR. Soil Biol. Biochem. 2014, 78, 170-181. [CrossRef]

13. Aziz, I.; Mahmood, T.; Islam, K.R. Effect of long term no-till and conventional tillage practices on soil quality. Soil Tillage Res. 2013, 131, 28-35. [CrossRef]

14. Bastida, F.; Zsolnay, A.; Hernández, T.; García, C. Past, present and future of soil quality indices: A biological perspective. Geoderma 2008, 147, 159-171. [CrossRef]

15. García-Ruiz, R.; Ochoa, V.; Hinojosa, M.B.; Carreira, J.A. Suitability of enzyme activities for the monitoring of soil quality improvement in organic agricultural systems. Soil Biol. Biochem. 2008, 40, 2137-2145. [CrossRef]

16. Kibblewhite, M.; Ritz, K.; Swift, M. Soil health in agricultural systems. Philos. Trans. R. Soc. B Biol. Sci. 2008, 363, 685-701. [CrossRef] [PubMed]

17. Keuskamp, J.A.; Dingemans, B.J.J.; Lehtinen, T.; Sarneel, J.M.; Hefting, M.M. Tea Bag Index: A novel approach to collect uniform decomposition data across ecosystems. Methods Ecol. Evol. 2013, 4, 1070-1075. [CrossRef]

18. Djukic, I.; Kepfer-Rojas, S.; Schmidt, I.K.; Larsen, K.S.; Beier, C.; Berg, B.; Verheyen, K. Early stage litter decomposition across biomes. Sci. Total Environ. 2018, 628-629, 1369-1394. [CrossRef] 
19. Tóth, Z.; Elisabeth, H.; Dombos, M. Tea Bag method: A new possibility to assess impacts of agri-environmental measures on soil functioning. Hung. Agric. Res. 2017, 26, 19-26.

20. International Union of Soil Science. World Reference Base for Soil Resources; FAO: Rome, Italy, 2006.

21. Chapman, H.D. Cation exchange capacity. In Methods of Soil Analysis: Part 1, Physical and Mineralogical Methods; Black, C.A., Ed.; American Society of Agronomy and Soil Science Society of America: Madison, WI, USA, 1965; pp. 891-901.

22. Houben, D.; Meunier, C.; Pereira, B.; Sonnet, P. Predicting the degree of phosphorus saturation using the ammonium acetate-EDTA soil test. Soil Use Manag. 2011, 27, 283-293. [CrossRef]

23. Lambrechts, T.; Gustot, Q.; Couder, E.; Houben, D.; Iserentant, A.; Lutts, S. Comparison of EDTA-enhanced phytoextraction and phytostabilisation strategies with Lolium perenne on a heavy metal contaminated soil. Chemosphere 2011, 85, 1290-1298. [CrossRef] [PubMed]

24. Aerts, R. Climate, leaf litter chemistry and leaf litter decomposition in terrestrial ecosystems: A triangular relationship. Oikos 1997, 79, 439-449. [CrossRef]

25. Melillo, J.M.; Aber, J.D.; Muratore, J.F. Nitrogen and lignin control of hardwood leaf litter decomposition dynamics. Ecology 1982, 63, 621-626. [CrossRef]

26. Cornwell, W.K.; Cornelissen, J.H.C.; Amatangelo, K.; Dorrepaal, E.; Eviner, V.T.; Godoy, O.; Hobbie, S.E.; Hoorens, B.; Kurokawa, H.; Pérez-Harguindeguy, N.; et al. Plant species traits are the predominant control on litter decomposition rates within biomes worldwide. Ecol. Lett. 2008, 11, 1065-1071. [CrossRef] [PubMed]

27. Zhang, D.; Hui, D.; Luo, Y.; Zhou, G. Rates of litter decomposition in terrestrial ecosystems: Global patterns and controlling factors. J. Plant Ecol. 2008, 1, 85-93. [CrossRef]

28. Pascault, N.; Cécillon, L.; Mathieu, O.; Hénault, C.; Sarr, A.; Lévêque, J.; Farcy, P.; Ranjard, L.; Maron, P.-A. In situ dynamics of microbial communities during decomposition of wheat, rape, and alfalfa residues. Microb. Ecol. 2010, 60, 816-828. [CrossRef] [PubMed]

29. Sauvadet, M.; Chauvat, M.; Fanin, N.; Coulibaly, S.; Bertrand, I. Comparing the effects of litter quantity and quality on soil biota structure and functioning: Application to a cultivated soil in Northern France. Appl. Soil Ecol. 2016, 107, 261-271. [CrossRef]

30. Govaerts, B.; Mezzalama, M.; Unno, Y.; Sayre, K.D.; Luna-Guido, M.; Vanherck, K.; Dendooven, L.; Deckers, J. Influence of tillage, residue management, and crop rotation on soil microbial biomass and catabolic diversity. Appl. Soil Ecol. 2007, 37, 18-30. [CrossRef]

31. Hazarika, S.; Parkinson, R.; Bol, R.; Dixon, L.; Russell, P.; Donovan, S.; Allen, D. Effect of tillage system and straw management on organic matter dynamics. Agron. Sustain. Dev. 2009, 29, 525-533. [CrossRef]

32. Arai, M.; Minamiya, Y.; Tsuzura, H.; Watanabe, Y.; Yagioka, A.; Kaneko, N. Changes in water stable aggregate and soil carbon accumulation in a no-tillage with weed mulch management site after conversion from conventional management practices. Geoderma 2014, 221-222, 50-60. [CrossRef]

33. Dimassi, B.; Mary, B.; Fontaine, S.; Perveen, N.; Revaillot, S.; Cohan, J.-P. Effect of nutrients availability and long-term tillage on priming effect and soil C mineralization. Soil Biol. Biochem. 2014, 78, 332-339. [CrossRef]

34. Kong, A.Y.Y.; Scow, K.M.; Córdova-Kreylos, A.L.; Holmes, W.E.; Six, J. Microbial community composition and carbon cycling within soil microenvironments of conventional, low-input, and organic cropping systems. Soil Biol. Biochem. 2011, 43, 20-30. [CrossRef] [PubMed]

35. Cookson, W.R.; Murphy, D.V.; Roper, M.M. Characterizing the relationships between soil organic matter components and microbial function and composition along a tillage disturbance gradient. Soil Biol. Biochem. 2008, 40, 763-777. [CrossRef]

36. Huang, M.; Jiang, L.; Zou, Y.; Xu, S.; Deng, G. Changes in soil microbial properties with no-tillage in Chinese cropping systems. Biol. Fertil. Soils 2013, 49, 373-377. [CrossRef]

37. Mathew, R.P.; Feng, Y.; Githinji, L.; Ankumah, R.; Balkcom, K.S. Impact of No-Tillage and Conventional Tillage Systems on Soil Microbial Communities. Appl. Environ. Soil Sci. 2012, 2012, e548620. [CrossRef]

38. Lupwayi, N.Z.; Clayton, G.W.; O’Donovan, J.T.; Harker, K.N.; Turkington, T.K.; Rice, W.A. Decomposition of crop residues under conventional and zero tillage. Can. J. Soil Sci. 2004, 84, 403-410. [CrossRef]

39. Wickings, K.; Grandy, A.S.; Reed, S.; Cleveland, C. Management intensity alters decomposition via biological pathways. Biogeochemistry 2010, 104, 365-379. [CrossRef]

40. Jacobs, A.; Ludwig, B.; Schmidt, J.H.; Bergstermann, A.; Rauber, R.; Joergensen, R.G. Influence of tillage on degradation kinetics using the litterbag method. Eur. J. Soil Biol. 2011, 47, 198-204. [CrossRef] 
41. Kainiemi, V.; Arvidsson, J.; Kätterer, T. Short-term organic matter mineralisation following different types of tillage on a Swedish clay soil. Biol. Fertil. Soils 2013, 49, 495-504. [CrossRef]

42. Kingery, W.L.; Wood, C.W.; Williams, J.C. Tillage and amendment effects on soil carbon and nitrogen mineralization and phosphorus release. Soil Tillage Res. 1996, 37, 239-250. [CrossRef]

43. Oorts, K.; Merckx, R.; Gréhan, E.; Labreuche, J.; Nicolardot, B. Determinants of annual fluxes of $\mathrm{CO}_{2}$ and $\mathrm{N}_{2} \mathrm{O}$ in long-term no-tillage and conventional tillage systems in northern France. Soil Tillage Res. 2007, 95, 133-148. [CrossRef]

44. Faucon, M.-P.; Houben, D.; Lambers, H. Plant functional traits: Soil and ecosystem services. Trends Plant Sci. 2017, 22, 385-394. [CrossRef] [PubMed]

45. Palm, C.; Blanco-Canqui, H.; DeClerck, F.; Gatere, L.; Grace, P. Conservation agriculture and ecosystem services: An overview. Agric. Ecosyst. Environ. 2014, 187, 87-105. [CrossRef]

(c) 2018 by the authors. Licensee MDPI, Basel, Switzerland. This article is an open access article distributed under the terms and conditions of the Creative Commons Attribution (CC BY) license (http://creativecommons.org/licenses/by/4.0/). 